medRxiv preprint doi: https://doi.org/10.1101/2020.10.14.20213033; this version posted November 24, 2020. The copyright holder for this preprint (which was not certified by peer review) is the author/funder, who has granted medRxiv a license to display the preprint in

perpetuity.
It is made available under a CC-BY-NC 4.0 International license .

\title{
Chronic Obstructive Pulmonary Disease in adults exposed to fine particles from a coal mine fire
}

Shivonne Prasad ${ }^{1,2}$, Caroline Gao ${ }^{1,3}$, Brigitte Borg ${ }^{1,2}$, Jonathan Broder ${ }^{1}$, David Brown ${ }^{1}$, Jillian Ikin ${ }^{1}$, Annie Makar $^{2}$, Tom McCrabb ${ }^{4}$, Ryan Hoy ${ }^{1,2}$, Bruce Thompson ${ }^{5}$, Michael J. Abramson ${ }^{1}$

${ }^{1}$ School of Public Health \& Preventive Medicine, Monash University, Melbourne, AU.

${ }^{2}$ Respiratory Medicine, The Alfred Hospital, Melbourne, AU.

${ }^{3}$ Centre for Youth Mental Health (Orygen), University of Melbourne, AU

${ }^{4}$ School of Population \& Global Health, University of Melbourne, Parkville, AU

${ }^{5}$ School of Health Sciences, Swinburne University of Technology, Hawthorn, AU.

\section{Correspondence:}

Professor Michael J. Abramson

School of Public Health and Preventive Medicine

Monash University

Level 2, 553 St Kilda Road, Melbourne, Vic. 3004, Australia.

E-mail: michael.abramson@monash.edu

Tel: +61399030573

Word Count: 3,168

Key words: COPD epidemiology. Respiratory measurement. Clinical epidemiology. Tobacco and the lung. 
medRxiv preprint doi: https://doi.org/10.1101/2020.10.14.20213033; this version posted November 24, 2020. The copyright holder for this preprint (which was not certified by peer review) is the author/funder, who has granted medRxiv a license to display the preprint in It is made available under a CC-BY-NC 4.0 International license .

\section{ABSTRACT}

Introduction. In 2014 the Hazelwood open cut coal mine burned for six weeks, exposing nearby residents to fine particulate matter $\left(\mathrm{PM}_{2.5}\right)$. The long-term health consequences are being evaluated as part of the Hazelwood Health Study (HHS). These analyses explore the association between $\mathrm{PM}_{2.5}$ and chronic obstructive pulmonary disease (COPD).

Methods. A sample of 346 exposed, and 173 unexposed, adults participated in the longitudinal Respiratory Stream of the HHS. Participants underwent spirometry and gas transfer measurements and answered validated respiratory questionnaires 3.5-4 years after the fire. Individual level mine fire-related $\mathrm{PM}_{2.5}$ exposure was modelled. Multivariate linear regression and logistic models were fitted to analyse associations between mean and peak $\mathrm{PM}_{2.5}$ exposure and clinical outcomes, stratified by smoking status.

Results. A $10 \mu \mathrm{g} / \mathrm{m}^{3}$ increase in mean $\mathrm{PM}_{2.5}$ exposure was associated with a $69 \%$ (95\% Cl: $11 \%$ to $158 \%$ ) increase in odds of spirometry consistent with COPD amongst non-smokers and increased odds of chest tightness (odds ratio; OR $1.30,95 \% \mathrm{Cl} 1.03$ to 1.64 ) and chronic cough (OR $1.24,95 \% \mathrm{Cl} 1.02$ to 1.51 ) in the previous 12 months in all participants. For current smokers, increments in mean $\mathrm{PM}_{2.5}$ exposure were associated with higher odds of chronic cough in the preceding 12 months (OR $2.13,95 \% \mathrm{Cl} 1.24$ to 3.65 ).

Discussion. Almost four years after a six-week period of coal fire $\mathrm{PM}_{2.5}$ exposure, we identified a doseresponse association between exposure and COPD in non-smokers. With climate change a likely contributor to increased risk of landscape fires, the findings will inform policy decisions during future sustained smoke events.

\section{KEY MESSAGES}

What is the key question? Are there long-term impacts of a six-week mine fire event generating $\mathrm{PM}_{2.5}$ on COPD and related respiratory symptoms in adults?

What is the bottom line? Almost 4 years after the mine fire, each $10 \mu \mathrm{g} / \mathrm{m}^{3}$ increase in $\mathrm{PM}_{2.5}$ exposure was associated with a $69 \%$ increase in odds of spirometry consistent with COPD amongst non-smokers, and a $30 \%$ increase in odds of chest tightness and $24 \%$ increase in odds of chronic cough amongst all participants. Amongst smokers, each $10 \mu \mathrm{g} / \mathrm{m}^{3}$ increase in $\mathrm{PM}_{2.5}$ was associated with a $113 \%$ increase in odds of chronic cough.

Why read on? With the recent megafires in Australia and the United States exposing communities to smoke for weeks to months, evidence of the long-term health impacts of similar duration $\mathrm{PM}_{2.5}$ generating pollution events are needed to inform the public health response. 
medRxiv preprint doi: https://doi.org/10.1101/2020.10.14.20213033; this version posted November 24,2020 . The copyright holder for this preprint (which was not certified by peer review) is the author/funder, who has granted medRxiv a license to display the preprint in

It is made available under a CC-BY-NC 4.0 International license .

\section{INTRODUCTION}

The industrial era, largely fuelled by coal, has seen an increase in fires occurring within coal seams and at coal mines in association with human activity and changes in climate patterns. [1] Prominent examples of coal mine fires occurring in close proximity to human settlements have raised concerns about risks to human health around the world.[2,3] Fires at the Jharia Coalfield in India and under the town of Centralia in Pennsylvania, illustrate instances where coal mine fires have led to mass relocation of residents arising from health and environmental effect concerns.[1,4]

The Centralia coal mine fire started in 1962 after local officials set fire to refuse in an abandoned coal pit. The fire then spread along an underground seam to tunnels beneath Centralia.[5] Emission of noxious gases and surface destabilization eventually made the town uninhabitable, with most residents evacuating between 1985 and 1991.[1,5] A health study comparing local residents with those of a nearby town suggested an increase in reported respiratory diseases in men and residents aged $40-79$ years relative to their comparators.[6] Two years later a lower rate of diagnosed respiratory disease in relocated residents suggesting some attenuation of effects after exposure to the fire ceased.[7]

Whilst coal mine fires near communities are widely reported, there remains limited peer reviewed literature on human health effects.[1-3] Analogous emissions from wildfires provide some insights into likely effects of exposure to smoke from coal mine fires.[1] Many of these studies assessed exposure to fine particulate matter with an aerodynamic diameter of less than $2.5 \mu \mathrm{m}\left(\mathrm{PM}_{2.5}\right)$.[8] A review of the health impacts of wildfire smoke in 2016 identified consistent evidence of smoke related respiratory morbidity, particularly asthma and chronic obstructive pulmonary disease (COPD).[8] Wildfire smoke exposure was associated with COPD related physician visits, $[9,10]$ emergency department presentations, $[11,12]$ hospitalisations $[13,14]$ as well as medication dispensing. $[9,15]$ However, almost all of the existing studies used administrative health records to evaluate short term smoke exposure effects. Clinical testing, including lung function measurements, to ascertain effects of bushfires or coal mine fire exposure was lacking.

In 2014, prolonged air pollution was generated from a fire at the Hazelwood open-cut brown coal mine in the Latrobe Valley in south-eastern Australia. Concerns were raised regarding the health of local residents, particularly in the nearby town of Morwell where smoke was visible for 6 weeks. The Hazelwood Health Study (HHS) was established to investigate potential longitudinal health outcomes in people who were exposed to smoke from the Hazelwood mine fire (www.hazelwoodhealthstudy.org.au). The HHS Hazelinks Stream which utilises administrative health datasets, has previously reported more COPD related emergency department presentations,[16] medications dispensed for respiratory condition[17] as well as visits to specialist respiratory services[18] during the mine fire period. The HHS Adult Survey, carried out 2.5 years after the mine fire, also identified higher risks of self-reported respiratory symptoms associated with individual-level mine fire $\mathrm{PM}_{2.5}$ exposure.[19] The aim of this further research was to evaluate clinical respiratory outcomes more than 3.5 years after the fire, particularly the risk of COPD and related respiratory symptoms, and their association with individual-level coalmine fire $\mathrm{PM}_{2.5}$ exposure. 
medRxiv preprint doi: https://doi.org/10.1101/2020.10.14.20213033; this version posted November 24,2020 . The copyright holder for this preprint (which was not certified by peer review) is the author/funder, who has granted medRxiv a license to display the preprint in It is made available under a CC-BY-NC 4.0 International license .

\section{Methods}

\section{Study design and setting}

This analysis examined cross-sectional data from the Hazelwood Health Study's Respiratory Stream, a longitudinal follow-up sub-study of the Adult Survey (see the methodology outlined elsewhere).[20] Clinical testing was conducted in Morwell (exposed) between August and December 2017, and in Sale (unexposed) between January and March 2018. Study data were collected and managed using REDCap (Research Electronic Data Capture)[21] electronic data capture tools hosted at Monash University (Victoria, Australia).

\section{Participants}

The Respiratory Stream participants were drawn from the Adult Survey cohort which comprised residents of Morwell or Sale who were aged at least 18 years at the time of the mine fire.[20] Adult Survey cohort members were excluded from eligibility to participate in the Respiratory Stream if they had specified no further contact, had unknown age, sex or were aged over 90 years. Potential participants were also excluded if they had a contraindication to spirometry, such as recent surgery, myocardial infarction, pneumothorax, pulmonary embolus, open pulmonary tuberculosis or known aneurysms.[22] A target sample size of 339 from Morwell and 170 from Sale was derived based on the ability to detect a $5 \mathrm{ml} /$ year or greater FEV 1 decline in exposed compared with non-exposed residents using a two-sample t-test with a two-sided $p$-value of 0.05 and $80 \%$ power. A weighted random sample (to correct for lower response rate in some subgroups of participants, such as young people) of 1,346 Adult Survey cohort members were selected for invitation into the Respiratory Stream, with those who had reported an asthma attack or taking asthma medication oversampled (40\%) for further evaluation in an asthmatic sample (see Figure 1). Invitation to participate was by mail, email and/or SMS, and recruitment continued until the target sample size was achieved.

Participant characteristics

For each participant, demographic characteristics, such as age, sex, ethnicity, employment status, educational background and occupational exposure (working in dusty or polluted environments, such as coal mines, farms or driving diesel trucks for at least six months) were drawn from the previously completed Adult Survey.[20] Physical characteristics, including height and weight, were measured by trained staff during clinical testing, and body mass index (BMI) was calculated.[23] Smoking history was taken and participants were classified as current smokers, ex-smokers (current non-smokers with $>100$ cigarettes in their lifetimes) or non-smokers ( $<100$ cigarettes in their lifetimes).[24]

\section{Exposure}

Due to the lack of ground-level air pollution monitoring from the start of the fire, mine fire-related $\mathrm{PM}_{2.5}$ concentrations were retrospectively modelled by the Australian Commonwealth Scientific and Industrial Research Organisation (CSIRO) Oceans \& Atmosphere using a chemical transport model that incorporated information on air monitoring, coal combustion and weather conditions.[25] The modelled 12-hourly concentrations were mapped to 12-hourly time-location diaries completed by participants as part of the Adult Survey, to estimate the level of exposure to mine-fire related $\mathrm{PM}_{2.5}$ for each individual. Two exposure metrics were considered: mean and peak daily mine fire-related $\mathrm{PM}_{2.5}$ exposure. Mean exposure was obtained by averaging the cumulative $\mathrm{PM}_{2.5}$ exposure across all the locations that participants visited over the exposure period (9 February - 31 March 2014). Peak exposure was obtained by assigning the highest 12hourly $\mathrm{PM}_{2.5}$ level from all locations, regardless of the time that the participant spent in that location. 
medRxiv preprint doi: https://doi.org/10.1101/2020.10.14.20213033; this version posted November 24,2020 . The copyright holder for this preprint (which was not certified by peer review) is the author/funder, who has granted medRxiv a license to display the preprint in It is made available under a CC-BY-NC 4.0 International license .

\section{Outcomes}

Respiratory symptoms and conditions

Self-reported respiratory symptoms and conditions were assessed with standardised questionnaires, adapted from the European Community Respiratory Health Survey II (ECRHSII)[26] and administered by trained interviewers.

\section{Respiratory function tests}

Trained investigators conducted objective measurements of respiratory function. Standardisation was achieved through the use of Standard Operating Procedures (SOPs), validated equipment, temperaturecontrolled rooms and utilisation of the same staff and equipment at both clinic sites. Preparation instructions were provided to participants at the time of booking the clinic visit.

Respiratory function was measured using the EasyOne Pro ${ }^{\mathrm{TM}}$ LAB Respiratory Analysis System (nnd Medical Technologies AG, Zürich, Switzerland). Spirometry was performed according to American Thoracic Society/European Respiratory Society (ATS/ERS) guidelines.[27] Parameters measured included FEV 1 , FVC and $\mathrm{FEV}_{1} / \mathrm{FVC}$. Z-scores for $\mathrm{FEV}_{1}, \mathrm{FVC}$ and $\mathrm{FEV}_{1} / \mathrm{FVC}$ were calculated using the Global Lung Initiative (GLI) 2012 spirometry reference equations.[28] This analysis focussed on spirometry measurements performed ten minutes after administration of $300 \mu \mathrm{g}$ Salbutamol via pressurised Metered Dose Inhaler and spacer (pMDI).[29]

Carbon monoxide transfer factor $\left(T_{L}(\mathrm{CO})\right.$ was measured using the single-breath testing technique according to ATS/ERS guidelines.[30] TLCo values were corrected for haemoglobin $(\mathrm{Hb})$ using standard equations from ATS/ERS guidelines.[30] Z-scores for $T_{L}$ co were calculated using the GLI 2017 reference equations.[31]

Definition of COPD and abnormal $T_{L}$ co

COPD was defined by post bronchodilator $\mathrm{FEV}_{1} / \mathrm{FVC}<5$ th percentile of predicted (lower limit of normal with $\mathrm{FEV}_{1} / \mathrm{FVC}$ z-scores<-1.645) and abnormal $\mathrm{T}_{L}$ Co was defined as haemoglobin corrected $\mathrm{T}_{L}$ co $<5$ th percentile of predicted ( $T_{L}$ co z-scores<-1.645). A similar definition for COPD was used in a recent population-based study on air pollution, lung function and COPD.[32]

\section{Statistical methods}

Descriptive statistics were used to summarise characteristics and clinical outcomes for the low, medium and high exposure groups in Morwell (tertiles of mean PM $_{2.5}$ exposure in Morwell) as well as the non-exposed Sale group. Crude statistical significance was assessed using Pearson chi-squared tests for categorical and ttests for continuous measures. Multivariate linear regression models were used to analyse the association between mean and peak $\mathrm{PM}_{2.5}$ exposure (controlling for key confounders) on continuous clinical outcomes. Logistic regression models were used for binary clinical outcomes. Oversampling of the asthmatic participants was corrected using the weighting method. Since smoking is the strongest risk factor for developing COPD, we tested whether the associations between $\mathrm{PM}_{2.5}$ exposure and outcomes differed between smoking groups by including an interaction between exposure and participants' smoking status (non-smoker, ex-smoker and current smoker) for all the outcome variables. Whether there was an overall interaction effect was tested using a Wald test of all interaction terms equal to zero. Sensitivity analyses 
medRxiv preprint doi: https://doi.org/10.1101/2020.10.14.20213033; this version posted November 24,2020 . The copyright holder for this preprint (which was not certified by peer review) is the author/funder, who has granted medRxiv a license to display the preprint in perpetuity.

It is made available under a CC-BY-NC 4.0 International license .

were performed with unweighted and complete case models. Multiple imputation by chained equation (MICE) was used to deal with missing data. Statistical analyses were performed using Stata version 15 (Stata Corporation, College Station, Texas 2015).

\section{Ethical considerations}

The Monash University Human Research Ethics Committee (MUHREC) approved the Hazelwood Health Study: Cardiovascular and Respiratory Streams (approval number 1078). All participants provided written informed consent.

\section{RESULTS}

As shown in Figure 1, 519 (39\%) adults participated in the Respiratory Stream clinics; 346 from Morwell and 173 from Sale. Their characteristics were comparable across exposed groups (tertiles) and the unexposed group in terms of age, ethnicity, highest educational qualification, smoking status, years of smoking (for current and ex-smokers), occupational exposure and respiratory medication use in last 3 months, see Table 1. Distributions of exposure level for each group are provided in Supplementary Figure S1. However, there were higher proportions of male and obese participants and a lower proportion of employed participants in the higher exposure group compared with lower exposure group. Table 2 displays lung function and respiratory symptoms for participants in exposure groups. There were no substantial differences in postbronchodilator spirometry or $T_{L}$ co between groups. However, respiratory symptoms in the last 12 months, including wheezing without an upper respiratory tract infection (URTI), chest tightness and chronic cough, were more prevalent in the higher exposure groups.

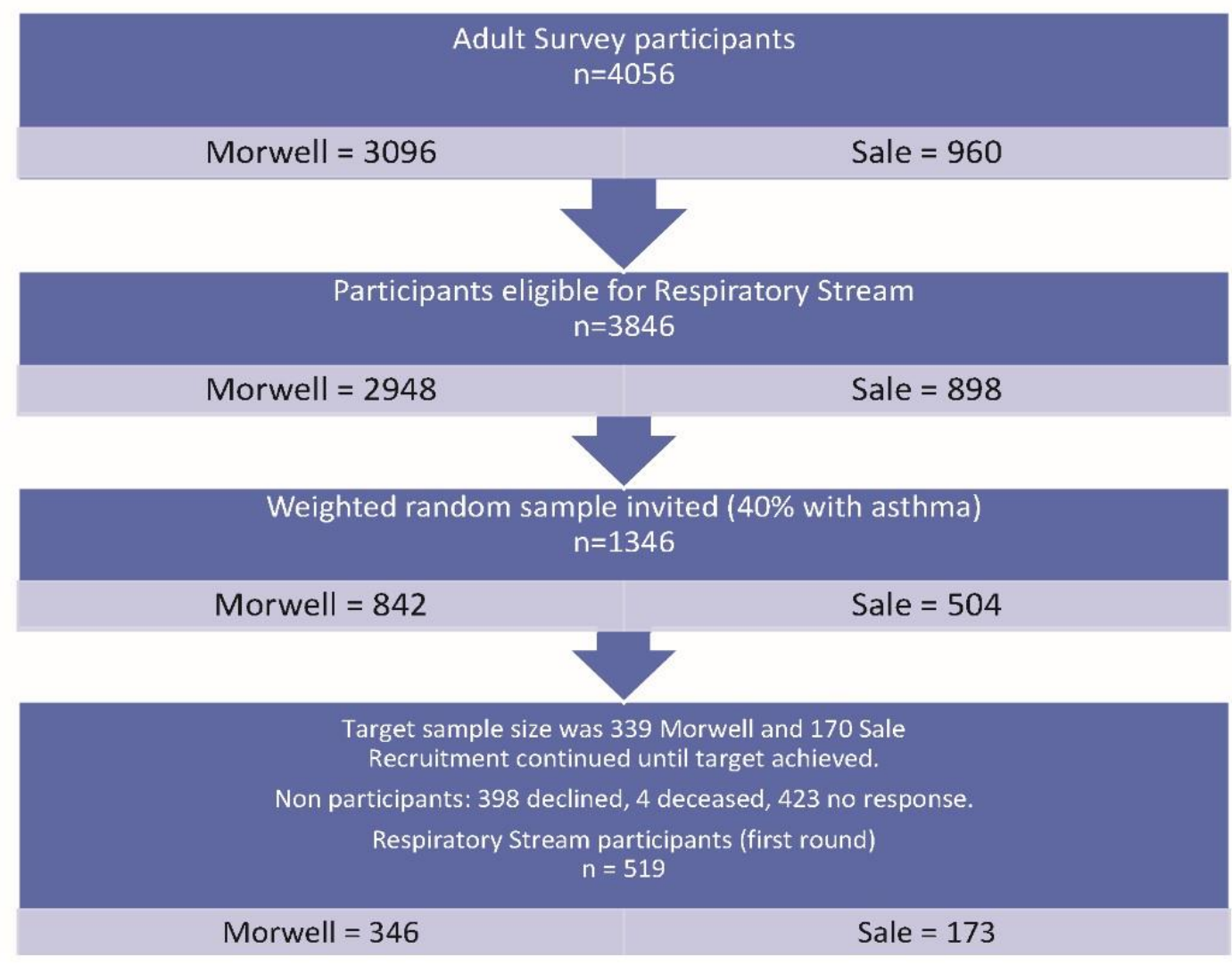

Figure 1. Participant recruitment flow diagram 


\begin{tabular}{|c|c|c|c|c|c|}
\hline Characteristics & $\begin{array}{c}\text { Sale } \\
\text { (no exposure) } \\
N=173\end{array}$ & $\begin{array}{c}\text { Morwell low } \\
\text { exposure } \\
\mathrm{N}=109\end{array}$ & $\begin{array}{c}\text { Morwell medium } \\
\text { exposure } \\
\mathrm{N}=113\end{array}$ & $\begin{array}{c}\text { Morwell high } \\
\text { exposure } \\
\mathrm{N}=124\end{array}$ & p-value \\
\hline \multicolumn{6}{|l|}{ Age group, n (weighted \%) } \\
\hline $45-64$ & $74(42 \%)$ & $43(44 \%)$ & $43(37 \%)$ & $50(37 \%)$ & \\
\hline $65+$ & $55(36 \%)$ & $30(29 \%)$ & $34(34 \%)$ & $39(38 \%)$ & \\
\hline Age, weighted mean (SD) & $57.3(20.0)$ & $54.7(14.3)$ & $54.5(15.3)$ & $56.7(14.7)$ & 0.50 \\
\hline Male, n (weighted \%) & $62(36 \%)$ & $43(46 \%)$ & $46(43 \%)$ & $62(56 \%)$ & 0.023 \\
\hline \multicolumn{6}{|l|}{ Employment status, $\mathrm{n}$ (weighted \%) } \\
\hline Employed & 89 (47\%) & $44(38 \%)$ & $46(40 \%)$ & $50(35 \%)$ & 0.021 \\
\hline Retired & $57(38 \%)$ & $32(32 \%)$ & $33(30 \%)$ & $37(37 \%)$ & \\
\hline Unable to work & $10(6 \%)$ & $15(16 \%)$ & $8(5 \%)$ & $15(12 \%)$ & \\
\hline Other (unemployed, studying, home duties and other) & $17(9 \%)$ & $18(13 \%)$ & $26(24 \%)$ & $22(16 \%)$ & \\
\hline \multicolumn{6}{|l|}{ Highest educational qualification, n (weighted \%) } \\
\hline Secondary up to year 10 & $34(17 \%)$ & $28(21 \%)$ & $29(22 \%)$ & $28(19 \%)$ & 0.79 \\
\hline Secondary year $11-12$ & $31(19 \%)$ & $24(23 \%)$ & $27(24 \%)$ & $21(17 \%)$ & \\
\hline University or other Tertiary Institute degree & $34(22 \%)$ & $22(19 \%)$ & $16(17 \%)$ & $21(16 \%)$ & \\
\hline \multicolumn{6}{|l|}{ BMI, n (weighted \%) } \\
\hline Underweight/Normal(BMI<25 kg/m²) & $40(24 \%)$ & $23(20 \%)$ & $21(18 \%)$ & $15(11 \%)$ & 0.06 \\
\hline Overweight $\left(25 \leq \mathrm{BMI}<30 \mathrm{~kg} / \mathrm{m}^{2}\right)$ & $66(38 \%)$ & $35(33 \%)$ & $31(29 \%)$ & $35(30 \%)$ & \\
\hline Obese $\left(\mathrm{BMI} \geq 30 \mathrm{~kg} / \mathrm{m}^{2}\right)$ & $67(38 \%)$ & $51(47 \%)$ & $61(53 \%)$ & $74(59 \%)$ & \\
\hline \multicolumn{6}{|l|}{ Smoking status, $\mathrm{n}$ (weighted \%) } \\
\hline Non-smoker & 82 (49\%) & $58(52 \%)$ & $60(54 \%)$ & $49(36 \%)$ & 0.10 \\
\hline Ex-smoker & 66 (39\%) & $35(33 \%)$ & 34 (33\%) & $51(47 \%)$ & \\
\hline Current smoker & $25(12 \%)$ & $16(15 \%)$ & 19 (13\%) & $24(17 \%)$ & \\
\hline Years of smoking among current and ex-smokers ( $N=270)$, weighted mean (SD) & $23.6(19.2)$ & $22.0(11.0)$ & $20.5(13.1)$ & $20.2(12.3)$ & 0.54 \\
\hline Occupational exposure, $\mathrm{n}$ (weighted \%) & $64(37 \%)$ & $43(44 \%)$ & $44(39 \%)$ & $54(46 \%)$ & 0.47 \\
\hline Use any SAMA/SABA* in the last 3 months, $n$ (weighted \%) & $64(31 \%)$ & $51(33 \%)$ & $53(36 \%)$ & $60(36 \%)$ & 0.82 \\
\hline LAMA/LABA and/or ICS+ use in the last 3 months, $n$ (weighted \%) & $9(4 \%)$ & $7(3 \%)$ & $9(6 \%)$ & $8(6 \%)$ & 0.87 \\
\hline
\end{tabular}

* SAMA=short-acting muscarinic agonist, SABA=short-acting beta-agonist.

+ LAMA=long-acting muscarinic agonist, LABA=long-acting beta-agonist, ICS=inhaled corticosteroids 


\begin{tabular}{|c|c|c|c|c|c|}
\hline Outcome variables & $\begin{array}{c}\text { Sale } \\
\text { (no exposure) } \\
\mathrm{N}=173 \\
\end{array}$ & $\begin{array}{l}\text { Morwell low exposure } \\
\qquad \mathrm{N}=109\end{array}$ & $\begin{array}{c}\text { Morwell medium } \\
\text { exposure } \\
\mathrm{N}=113 \\
\end{array}$ & $\begin{array}{l}\text { Morwell high exposure } \\
\qquad \mathrm{N}=124\end{array}$ & p-value \\
\hline & n (weighted\%) & n (weighted\%) & n (weighted\%) & n (weighted\%) & \\
\hline Spirometric COPD & $24(14 \%)$ & $9(6 \%)$ & $14(9 \%)$ & $12(9 \%)$ & 0.27 \\
\hline Abnormal $T_{L} c o$ & $18(11 \%)$ & $9(7 \%)$ & $15(10 \%)$ & $14(12 \%)$ & 0.50 \\
\hline \multirow[t]{2}{*}{ Spirometric COPD \& abnormal $\mathrm{T}_{\mathrm{L}} \mathrm{co}$} & $7(4 \%)$ & $2(1 \%)$ & $6(4 \%)$ & $6(5 \%)$ & 0.27 \\
\hline & Weighted mean (SD) & Weighted mean (SD) & Weighted mean (SD) & Weighted mean (SD) & \\
\hline \multicolumn{6}{|l|}{ Spirometry - post BD } \\
\hline $\mathrm{FEV}_{1}$, Litres & $2.9(1.1)$ & $3.0(0.8)$ & $2.9(0.8)$ & $2.9(0.7)$ & 0.86 \\
\hline $\mathrm{FEV}_{1}$ z score & $0.0(1.5)$ & $0.0(1.0)$ & $-0.3(1.1)$ & $-0.2(1.0)$ & 0.22 \\
\hline $\mathrm{FEV}_{1} \%$ Predicted & $99.3(22.2)$ & $99.5(13.9)$ & $95.9(16.3)$ & $97.0(14.9)$ & 0.29 \\
\hline FVC, Litres & $3.7(1.3)$ & $3.8(1.1)$ & $3.7(1.0)$ & $3.8(0.8)$ & 0.94 \\
\hline FVC z score & $0.2(1.2)$ & $0.0(0.9)$ & $-0.1(0.9)$ & $-0.1(0.8)$ & 0.10 \\
\hline FVC \%Predicted & $102.6(18.4)$ & $100.7(13.3)$ & $98.7(13.5)$ & $99.2(12.0)$ & 0.13 \\
\hline $\mathrm{FEV}_{1} / \mathrm{FVC}$ & $76.5(12.7)$ & $78.7(7.0)$ & $77.2(9.2)$ & $77.0(8.5)$ & 0.20 \\
\hline $\mathrm{FEV}_{1} / \mathrm{FVC}$ score & $-0.3(1.4)$ & $-0.1(0.9)$ & $-0.3(1.0)$ & $-0.3(1.0)$ & 0.48 \\
\hline \multicolumn{6}{|l|}{$T_{L}$ CO } \\
\hline $\mathrm{T}_{\mathrm{L}} \mathrm{co}$ z score & $0.0(1.7)$ & $-0.2(1.0)$ & $-0.1(1.1)$ & $-0.1(1.3)$ & 0.71 \\
\hline $\mathrm{T}_{\text {LCO }}$ \% Predicted & $101.0(26.0)$ & $98.2(15.0)$ & $99.1(17.4)$ & $99.2(19.9)$ & 0.68 \\
\hline $\mathrm{T}_{\mathrm{L}} \mathrm{co} \mathrm{Hb}$ corrected $\mathrm{z}$ score & $0.0(1.7)$ & $-0.1(0.9)$ & $-0.1(1.1)$ & $-0.1(1.2)$ & 0.73 \\
\hline $\mathrm{T}_{\mathrm{L}} \mathrm{co} \mathrm{Hb}$ corrected \%Predicted & $102.0(24.9)$ & $98.8(14.3)$ & $99.6(17.3)$ & $99.8(19.1)$ & 0.55 \\
\hline \multicolumn{6}{|c|}{ Respiratory symptoms in the last 12 months } \\
\hline Wheeze & $66(34 \%)$ & $53(41 \%)$ & $52(38 \%)$ & $71(50 \%)$ & 0.08 \\
\hline Wheeze and breathlessness & $46(23 \%)$ & $43(30 \%)$ & $36(25 \%)$ & 46 (31\%) & 0.47 \\
\hline Wheeze without URTI & $49(23 \%)$ & $38(27 \%)$ & $36(23 \%)$ & $61(43 \%)$ & $<0.001$ \\
\hline Chest tightness & $28(15 \%)$ & $22(15 \%)$ & $30(19 \%)$ & $36(27 \%)$ & 0.036 \\
\hline Dyspnoea at rest & $26(13 \%)$ & $20(16 \%)$ & $22(14 \%)$ & $28(19 \%)$ & 0.60 \\
\hline Dyspnoea after exercise & 76 (42\%) & 65 (54\%) & 49 (38\%) & $68(52 \%)$ & 0.049 \\
\hline Woken with dyspnoea & $12(6 \%)$ & $17(12 \%)$ & $20(14 \%)$ & $16(10 \%)$ & 0.20 \\
\hline Woken with cough & $56(29 \%)$ & $52(45 \%)$ & $42(34 \%)$ & $54(39 \%)$ & 0.11 \\
\hline Chronic cough & $55(29 \%)$ & 47 (39\%) & $52(45 \%)$ & 67 (48\%) & 0.040 \\
\hline Chronic phlegm & $25(13 \%)$ & $14(13 \%)$ & $21(16 \%)$ & $28(22 \%)$ & 0.22 \\
\hline
\end{tabular}


medRxiv preprint doi: https://doi.org/10.1101/2020.10.14.20213033; this version posted November 24,2020 . The copyright holder for this preprint (which was not certified by peer review) is the author/funder, who has granted medRxiv a license to display the preprint in

It is made available under a CC-BY-NC 4.0 International license .

Adjusted associations between $\mathrm{PM}_{2.5}$ exposure, respiratory symptoms and lung function are displayed in Table 3. A $10 \mu \mathrm{g} / \mathrm{m}^{3}$ increase in mean $\mathrm{PM}_{2.5}$ exposure was associated with a $30 \%(95 \% \mathrm{Cl}$ : $3 \%$ to $64 \%$ increase in the odds of chest tightness in the previous 12 months as well as a $24 \%$ (95\% Cl: $2 \%$ to $51 \%$ ) increase in odds of chronic cough. Dose-response relationships between $\mathrm{PM}_{2.5}$ exposure and post $\mathrm{BD}$ spirometry and $\mathrm{T}_{\mathrm{L}} \mathrm{CO} \mathrm{z}$ scores were not observed.

Table 3. Adjusted associations (Odds Ratios and 95\% Confidence Intervals) between $\mathrm{PM}_{2.5}$ exposure, respiratory symptoms and lung function

\begin{tabular}{|c|c|c|c|c|}
\hline & \multicolumn{2}{|c|}{$\begin{array}{c}\text { Mean exposure model } \\
\left(10 \mu \mathrm{g} / \mathrm{m}^{3}\right)\end{array}$} & \multicolumn{2}{|c|}{$\begin{array}{c}\text { Peak exposure model } \\
\left(100 \mu \mathrm{g} / \mathrm{m}^{3}\right)\end{array}$} \\
\hline & Adj OR (95\% Cl) & p-value & Adj OR (95\% Cl) & p-value \\
\hline \multicolumn{5}{|c|}{ Respiratory symptoms in the last 12 months ${ }^{*}$} \\
\hline Wheeze & $1.13(0.89,1.43)$ & 0.31 & $1.00(0.89,1.13)$ & 0.99 \\
\hline Wheeze and breathlessness & $1.00(0.76,1.32)$ & 1.00 & $0.92(0.80,1.06)$ & 0.26 \\
\hline Wheeze without URTI & $1.19(0.96,1.48)$ & 0.11 & $1.07(0.96,1.20)$ & 0.22 \\
\hline Chest tightness & $1.30(1.03,1.64)$ & 0.026 & $1.08(0.96,1.21)$ & 0.22 \\
\hline Dyspnoea at rest & $1.02(0.77,1.33)$ & 0.91 & $1.02(0.87,1.19)$ & 0.84 \\
\hline Dyspnoea after exercise & $1.08(0.87,1.34)$ & 0.48 & $0.99(0.89,1.11)$ & 0.88 \\
\hline Woken with dyspnoea & $0.84(0.63,1.12)$ & 0.23 & $0.92(0.78,1.08)$ & 0.29 \\
\hline Woken with cough & $0.97(0.77,1.22)$ & 0.78 & $0.95(0.84,1.07)$ & 0.39 \\
\hline Chronic cough & $1.24(1.02,1.51)$ & 0.035 & $1.06(0.95,1.18)$ & 0.33 \\
\hline Chronic phlegm & $1.23(0.93,1.62)$ & 0.15 & $1.02(0.88,1.17)$ & 0.83 \\
\hline Lung function $^{+}$ & Adj OR $(95 \% \mathrm{Cl})$ & p-value & Adj OR (95\% Cl) & p-value \\
\hline Spirometric COPD & $0.92(0.67,1.26)$ & 0.60 & $1.02(0.86,1.20)$ & 0.82 \\
\hline \multirow[t]{2}{*}{ Abnormal $T_{L} c o$} & $1.18(0.84,1.65)$ & 0.35 & $1.05(0.89,1.24)$ & 0.55 \\
\hline & $\operatorname{Adj} \beta(95 \% \mathrm{Cl})$ & p-value & $\operatorname{Adj} \beta(95 \% \mathrm{Cl})$ & p-value \\
\hline Post BD FEV ${ }_{1}$ z score & $0.02(-0.09,0.13)$ & 0.68 & $0.03(-0.03,0.08)$ & 0.30 \\
\hline Post BD FEV $1 / F V C$ z score & $0.04(-0.06,0.13)$ & 0.44 & $0.00(-0.05,0.05)$ & 0.99 \\
\hline Corrected $T_{L}$ co $z$ score & $-0.05(-0.18,0.08)$ & 0.48 & $0.02(-0.05,0.09)$ & 0.60 \\
\hline
\end{tabular}

${ }^{*}$ Adjusted for smoking status, location of the participant (Morwell vs. Sale), BMI category, occupational exposure, nasal allergies/hayfever, employed or not and having a certificate, university or other tertiary institute degrees.

${ }^{+}$Adjusted for smoking status, location of the participant (Morwell vs. Sale), BMI category, employed or not and having a certificate, university or other tertiary institute degrees.

Figure 2 presents the results from logistic regression models for respiratory symptoms when interactions between exposure and smoking status were included. For ease of interpretation, we report the estimated OR associated with exposure $\left(a 10 \mu \mathrm{g} / \mathrm{m}^{3}\right.$ increase in mean $\mathrm{PM}_{2.5}$ or a 100 $\mu \mathrm{g} / \mathrm{m}^{3}$ increase in peak $\mathrm{PM}_{2.5}$ exposure) in each smoking group separately. A dose-response relationship existed between $10 \mu \mathrm{g} / \mathrm{m}^{3}$ increases in mean $\mathrm{PM}_{2.5}$ and chest tightness in the previous 12 months in non-smokers (OR 1.46, 95\% Cl 1.07, 2.00) and current smokers (OR 1.70, 95\% Cl 1.05, 2.75), but not in ex-smokers. For chronic cough, there was strong evidence for a dose-response relationship in current smokers (OR 2.13,95\% $\mathrm{Cl} 1.24,3.65$ for each $10 \mu \mathrm{g} / \mathrm{m}^{3}$ increase in mean $\mathrm{PM}_{2.5}$. There was also some evidence suggesting a dose response relationship among non-smokers for wheeze without URTI in the previous 12 months and each $10 \mu \mathrm{g} / \mathrm{m}^{3}$ increase in mean $\mathrm{PM}_{2.5}$ (see Figure 2 and Table S1 in Supplementary Material). 
medRxiv preprint doi: https://doi.org/10.1101/2020.10.14.20213033; this version posted November 24,2020 . The copyright holder for this preprint (which was not certified by peer review) is the author/funder, who has granted medRxiv a license to display the preprint in perpetuity.

It is made available under a CC-BY-NC 4.0 International license.

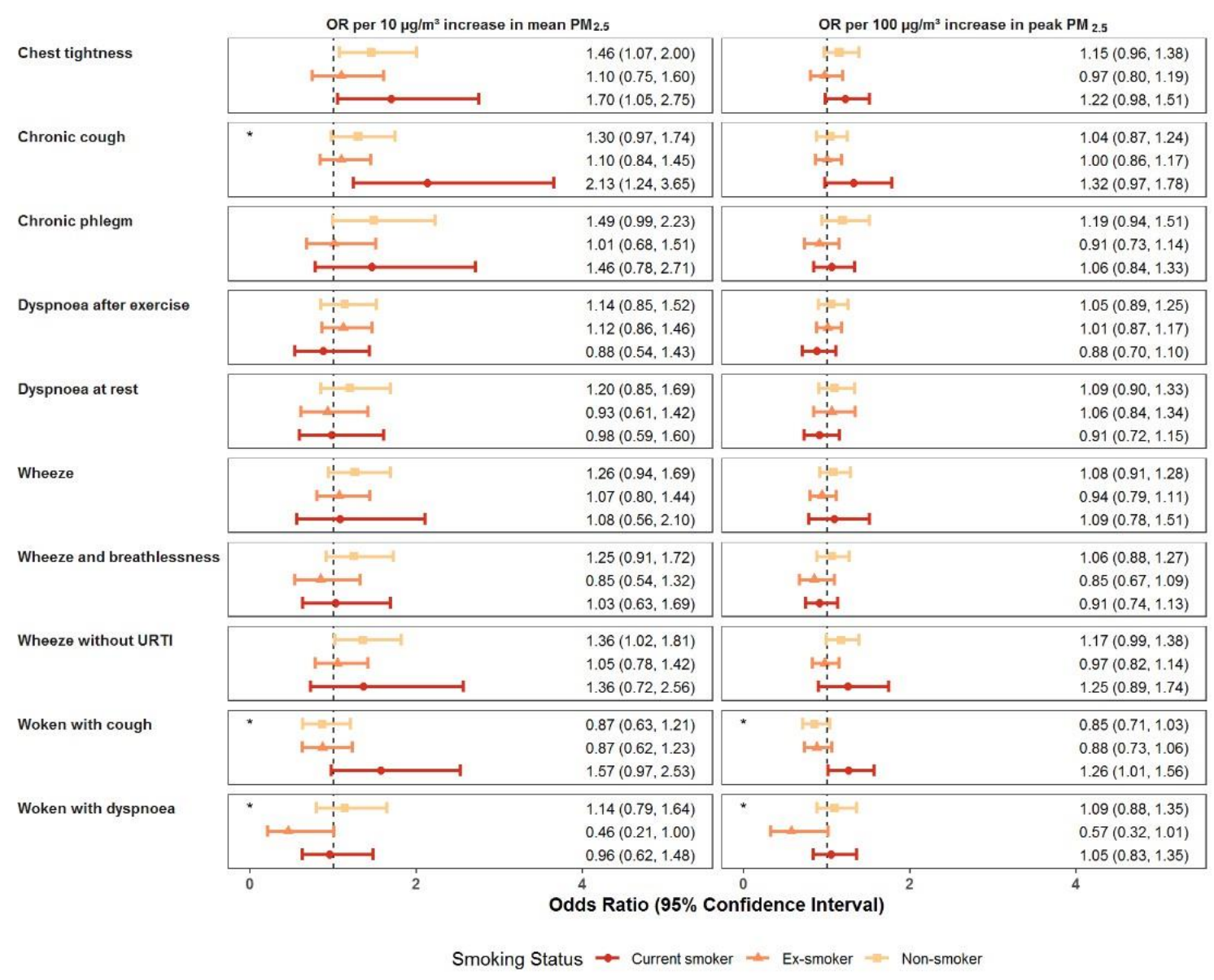

Figure 2. Forest plots of the estimated effects of $\mathrm{PM}_{2.5}$ exposure on respiratory symptoms in the past 12 months for each smoking group. Note: The OR were estimated using multivariate logistic regression with an interaction between exposure and smoking status. All models were also adjusted for age, gender, location of the participant (Morwell vs. Sale), BMI category, occupational exposure, nasal allergies/hayfever, employed or not and having a certificate university or other tertiary institute degrees. * indicates evidence of an overall interaction effect ( $p$-value $<0.1$ from Wald test of all interaction terms equal to zero). 
medRxiv preprint doi: https://doi.org/10.1101/2020.10.14.20213033; this version posted November 24,2020 . The copyright holder for this preprint (which was not certified by peer review) is the author/funder, who has granted medRxiv a license to display the preprint in perpetuity

It is made available under a CC-BY-NC 4.0 International license .

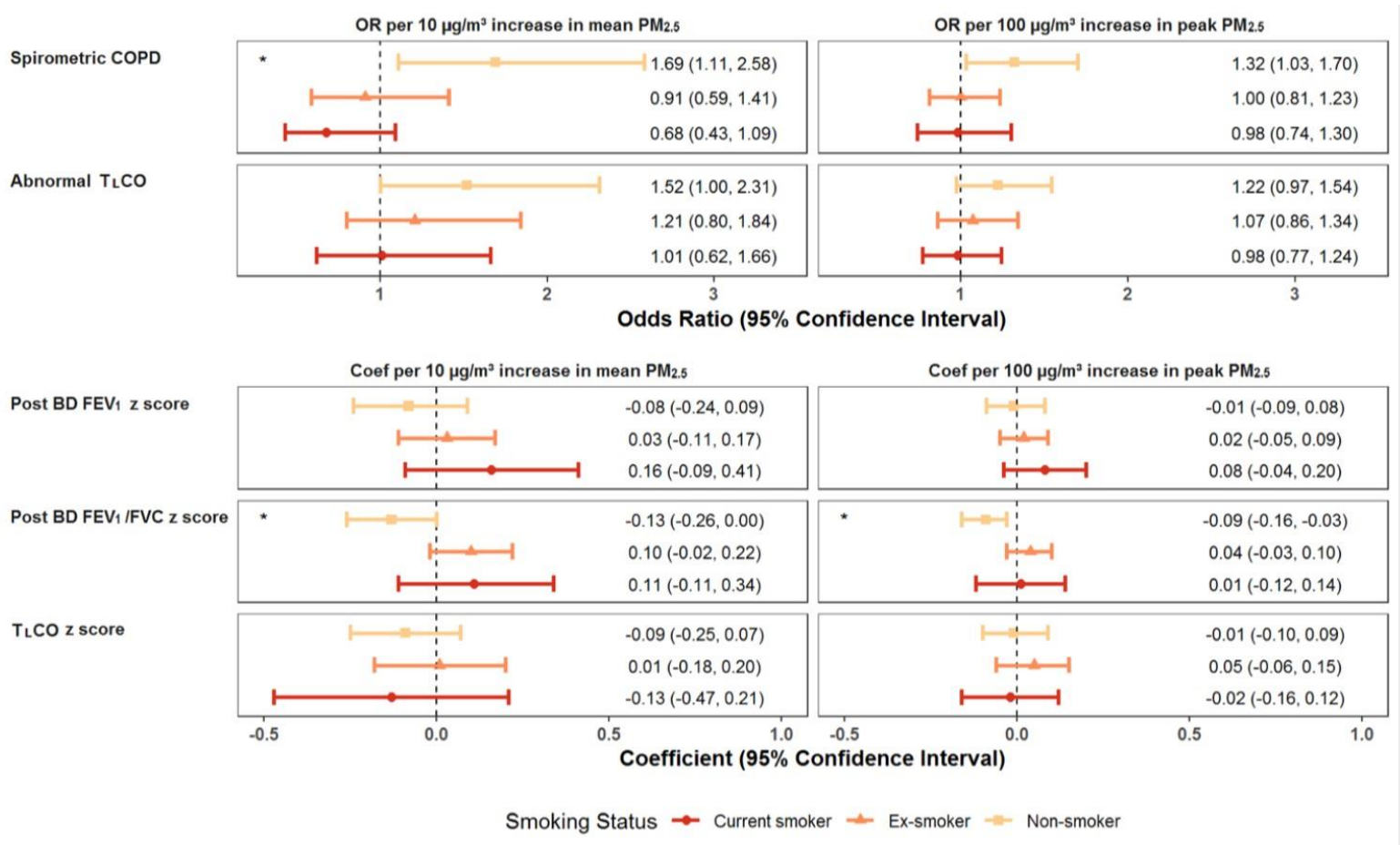

Figure 3. Forest plots of the estimated effect of $\mathrm{PM}_{2.5}$ exposure on lung function for each smoking group. Note: TLCO values are corrected for haemoglobin level. The ORs and coefficients were estimated using multivariate logistic and linear regression models with an interaction between exposure and smoking status. All models were adjusted for location of the participant (Morwell vs. Sale), BMI category occupational exposure, employment and higher education. * indicates evidence of an overall interaction effect ( $p$-value $<0.1$ from Wald test of all interaction terms equal to zero).

Figure 3 presents the results from regression models for lung function when interactions between exposure and smoking status were included. Among non-smokers, the interaction models estimated a $69 \%$ (95\% Cl: $11 \%, 158 \%$ ) increase in the odds of spirometric COPD, a $52 \%$ increase in the odds of abnormal $\mathrm{T}_{\llcorner} \mathrm{CO}(95 \% \mathrm{Cl}: 0 \%, 131 \%)$ and a 0.13 unit $(95 \% \mathrm{Cl}: 0.00,0.26)$ reduction in post $\mathrm{BD} \mathrm{FEV} 1 / \mathrm{FVC}$ $\mathrm{z}$ score per $10 \mu \mathrm{g} / \mathrm{m}^{3}$ increment in mean exposure to $\mathrm{PM}_{2.5}$. Among non-smokers, associations were also observed between $100 \mu \mathrm{g} / \mathrm{m}^{3}$ increments in peak exposure to $\mathrm{PM}_{2.5}$. and increased odds of Spirometric COPD, decreased BD FEV $1 / F V C$ z score and weaker evidence of increased odds of abnormal $T_{L}$ co. Evidence of interaction effects between exposure and smoking status were present for spirometric COPD and post BD FEV 1 /FVC $z$ score but not abnormal $\mathrm{T}_{L} \mathrm{Co}$ (see Figure 3 and Table S2 in the Supplementary Material).

\section{DISCUSSION}

This analysis found that COPD, as defined by a post bronchodilator $\mathrm{FEV}_{1} / \mathrm{FVC}$ ratio less than the lower limit of normal, was associated with both mean and peak $\mathrm{PM}_{2.5}$ exposure from a coal mine fire in non-smoking individuals 3.5 to 4 years after exposure. In all participants, an association was also observed between mean mine-fire related $\mathrm{PM}_{2.5}$ exposure and respiratory symptoms (chest tightness and chronic cough) consistent with airflow obstruction. Effect modification by smoking was apparent for the associations between respiratory symptoms and $\mathrm{PM}_{2.5}$ exposure. This was clearest 
medRxiv preprint doi: https://doi.org/10.1101/2020.10.14.20213033; this version posted November 24,2020 . The copyright holder for this preprint (which was not certified by peer review) is the author/funder, who has granted medRxiv a license to display the preprint in

It is made available under a CC-BY-NC 4.0 International license .

for chronic cough in the previous 12 months, with increments in mean $\mathrm{PM}_{2.5}$ exposure associated with a doubling of the odds of this symptom in current smokers.

The exposure-response relationship between PM2.5 and spirometric COPD in non-smokers in this study was consistent with findings in the study of Huang et al,[33] who investigated the association between COPD and $\mathrm{PM}_{2.5}$ in Taiwanese non-smokers. The relationship was also seen in a Taiwanese study by Guo et al[34] and a Chinese study from Zhao et al[35] who found $\mathrm{PM}_{2.5}$ exposure was associated with increased risk of COPD. Further, Zhao et al[35] suggested that $\mathrm{PM}_{2.5}$ and cigarette smoking exposure may have a "synergistic effect" in the development and progression of COPD. It is not clear why a similar association was not seen in current and ex-smokers in this study. It may be due to small numbers of participants in the current and ex-smoker in this study cohort or that the length of $\mathrm{PM}_{2.5}$ exposure in this study was weeks to months compared to years in the Zhao study.

The lack of an effect on spirometry for smokers and ex-smokers exposed to mine fire $\mathrm{PM}_{2.5}$ may equally relate to concurrent inhaled medication use, with these individuals potentially more likely to have used such medications compared to non-smokers. Lung function studies of asthmatics after a wildfire event have suggested a counter-intuitive preservation of lung function compared to nonasthmatics, with the possibility of a protective effect from the use of medications in this population. [8] Studies of COPD in non-smokers suggest a lower prevalence of respiratory symptoms, including chronic cough, reducing the likelihood of medication-seeking in this population.[36]

From an epidemiological perspective, a quarter to a third of COPD occurs in non-smokers, with the proportion greater in low-middle compared to high income countries.[36] This may relate to an important role for indoor air pollution in the pathogenesis of COPD in non-smokers, with $45 \%$ of non-smokers reported to be exposed to biomass and $73 \%$ to coal smoke.[36]

In general, there are limited data on the effects of particulate matter from coal mine fires on spirometry and our study provides a valuable addition to knowledge. Whilst comparison to other studies of coal mine fires is difficult for this reason, the similar emission profile between forest and coal mine fires allows comparison with the landscape fire literature.[1] Studies on the health impacts of wildfire smoke have found increasing evidence of a link with COPD using data on hospitalisations, physician visits and reliever medications.[8] However there were little data on effects on spirometry, with the exception of declines in peak expiratory flow among non-asthmatic children associated with wildfire exposure.[8] There was also little literature available on wild-fire smoke exposure lasting for up to six weeks, like the Hazelwood mine fire exposure. Wildfires often tend to be episodic and short in duration, and exposed populations from individual events are often small.[8] However, climate change may be contributing to increasing incidence of catastrophic wildfires globally, such as the recent megafires in Australia which burned over a six month period and exposed more than 10 million people.[37]

Declines in lung function (particularly FEV 1 ) after smoke exposure are commonly reported from studies of cross shift and cross season variations in wildfire fire fighters.[37] One study reported an association between levoglucosan (a woodsmoke marker) and decline in $\mathrm{FEV}_{1}$ among wildland firefighters.[38] However, another study found no association between a decline in lung function and smoke components such as $\mathrm{PM}_{3.5}$, acrolein, formaldehyde or carbon monoxide exposure.[39] 
medRxiv preprint doi: https://doi.org/10.1101/2020.10.14.20213033; this version posted November 24, 2020. The copyright holder for this

preprint (which was not certified by peer review) is the author/funder, who has granted medRxiv a license to display the preprint in

It is made available under a CC-BY-NC 4.0 International license.

The role of wildfire smoke causing sustained changes in lung function among adult fire fighters is unclear with contradictory results from existing studies.[37] In some children with asthma, peak expiratory flow rates have been measured to assess response to wildfires.[8] One small study measured $\mathrm{FEV}_{1}$ and peak flow prior to, and 1 month after, wildfires with high $\mathrm{PM}_{2.5}$ levels and found stable lung function, but also elevated sputum eosinophils in two subjects tested during the fires, suggesting an acute inflammatory effect.[40]

\section{Strengths \& Limitations}

A major strength of our study was the measurement of lung function through spirometry, to enable an objective definition of COPD. To our knowledge, there were no comparable data available from other populations exposed to coal mine fires. Wildfire studies have largely focused on hospital and primary care presentations or medication dispensing.[8] This stream achieved the required sample size. The findings build upon previously reported HHS respiratory health findings which have utilised administrative health datasets[16-18] and self-reported symptoms.[19]

Not relying on participants recalling their smoke exposure levels, an additional strength of our study was the estimation of individual exposures to $\mathrm{PM}_{2.5}$ from a combination of detailed time-location diaries and spatially and temporally resolved modelled $\mathrm{PM}_{2.5}$ concentrations using a chemical transport model. Whilst it is possible that some participants may have had difficulty recalling their precise locations and dates more than two years after the fire, considerable effort was made to manually review any detected inconsistencies in participant's time-location diaries.

However, a limitation of the study includes that it was essentially a cross-sectional analysis and it was not possible to imply causation between $\mathrm{PM}_{2.5}$ exposure and COPD in non-smokers.

\section{Conclusions}

Our study found an association in non-smokers exposed to $\mathrm{PM}_{2.5}$ from an open cut brown coal mine fire and increased risk of spirometry defined COPD almost four years after exposure Conversely, we also found a pronounced association between respiratory symptoms and $\mathrm{PM}_{2.5}$ exposure in smokers. These findings have important public health implications, as a better understanding of the exposureresponse relationships across a range of $\mathrm{PM}_{2.5}$ exposure levels and durations would help inform policy decisions including evidence-based exposure reduction strategies, and long-term health service needs, for smoke-exposed communities. These may be particularly relevant to communities exposed to large-scale landscape fires such as those recently in Australia and the United States, and to future landscape fire events Our study also highlighted the importance of objective measurement of pulmonary impairment through spirometry, given that reliance on symptoms alone does not reliably identify disease, particularly in non-smokers. Long term followup of this exposed cohort may provide valuable insights into the incidence and prognosis of COPD in coal-mine fire $\mathrm{PM}_{2.5}$ exposed non-smokers. 
medRxiv preprint doi: https://doi.org/10.1101/2020.10.14.20213033; this version posted November 24, 2020. The copyright holder for this preprint (which was not certified by peer review) is the author/funder, who has granted medRxiv a license to display the preprint in It is made available under a CC-BY-NC 4.0 International license .

\section{ACKNOWLEDGMENTS}

We gratefully acknowledge the contribution of all participating community members. We also thank Susan Denny, Kylie Sawyer, Shantelle Allgood and Kristina Thomas from the Monash University School of Rural Health who assisted with recruitment and data collection.

\section{COMPETING INTERESTS}

Michael Abramson holds investigator initiated grants for unrelated research from Pfizer and Boehringer-Ingelheim. He has also undertaken an unrelated consultancy for Sanofi and received a speaker's fee from GSK. The other authors declare no conflicts of interest.

\section{FUNDING}

The Hazelwood Health Study is funded by the Victorian Department of Health \& Human Services. The paper presents the views of the authors and does not represent the views of the Department.

\section{CONTRIBUTORSHIP}

SP led the drafting of the work and revising it critically, and contributed to interpretation of the data. $\mathrm{BB}$ contributed to the design of the work, the acquisition, analysis and interpretation of data, drafting the work and revising it critically. CG and JB contributed to the analysis and interpretation of data, drafting the work and revising it critically. DB contributed to the acquisition of data, drafting the work and revising it critically. Jl contributed to the design of the work, the acquisition and interpretation of data, drafting the work and revising it critically. AM and TM contributed to the design of the work, the acquisition and interpretation of data, drafting the work and revising it critically. $\mathrm{RH}$ and BT contributed to the conception and design of the work, the interpretation of data, drafting the work and revising it critically. MA contributed to the conception and design of the work, the acquisition, analysis and interpretation of data, drafting the work and revising it critically. All authors approved the final version and agreed to be accountable for all aspects of the work in ensuring that questions related to the accuracy or integrity of any part of the work were appropriately investigated and resolved. 
medRxiv preprint doi: https://doi.org/10.1101/2020.10.14.20213033; this version posted November 24,2020 . The copyright holder for this preprint (which was not certified by peer review) is the author/funder, who has granted medRxiv a license to display the preprint in

It is made available under a CC-BY-NC 4.0 International license .

\section{REFERENCES}

1. Melody SM, Johnston FH. Coal mine fires and human health: What do we know? Int J Coal Geol 2015;152:1-14. doi: 10.1016/j.coal.2015.11.001

2. Stracher G, Taylor T. Coal fires burning out of control around the world: Thermodynamic recipe for environmental catastrophe. Int J Coal Geol 2004;59:7-17. doi: 10.1016/j.coal.2003.03.002

3. Song Z, Kuenzer C. Coal fires in China over the last decade: A comprehensive review. Int J Coal Geol 2014;133:72-99. doi: https://doi.org/10.1016/j.coal.2014.09.004

4. Sinha PR. Mine fires in Indian coalfields. Energy 1986;11(11):1147-54. doi: https://doi.org/10.1016/0360-5442(86)90051-4

5. Stracher $G$, Nolter M, Schroeder $P$, et al. The great Centralia mine fire: a natural laboratory for the study of coalfires. In: FJ P, ed. Excursions in geology and history: field trips in the Middle Atlantic States: Geological Society of America field guide2006:33-45.

6. Streufert S. Report on the Baseline Health Status for Centralia and Marion Heights, PA: Final Report. Pennsylvania State University: The Division 1985.

7. Streufert S, Baum A. Final Report on Health Status for Centralia and Marion Heights, Pa: Milton S. Hershey Medical Center, The Pennsylvania State University 1987.

8. Reid CE, Brauer M, Johnston FH, et al. Critical Review of Health Impacts of Wildfire Smoke Exposure. Environmental Health Perspectives 2016;124(9):1334-43. doi: doi:10.1289/ehp.1409277

9. Yao J, Eyamie J, Henderson SB. Evaluation of a spatially resolved forest fire smoke model for population-based epidemiologic exposure assessment. J Expo Sci Environ Epidemiol 2016;26(3):233-40. doi: 10.1038/jes.2014.67 [published Online First: 2014/10/08]

10. Henderson SB, Brauer M, Macnab YC, et al. Three measures of forest fire smoke exposure and their associations with respiratory and cardiovascular health outcomes in a populationbased cohort. Environ Health Perspect 2011;119(9):1266-71. doi: 10.1289/ehp.1002288 [published Online First: 2011/06/11]

11. Reid CE, Jerrett M, Tager IB, et al. Differential respiratory health effects from the 2008 northern California wildfires: A spatiotemporal approach. Environ Res 2016;150:227-35. doi: 10.1016/j.envres.2016.06.012 [published Online First: 2016/06/19]

12. Johnston FH, Purdie $S$, Jalaludin B, et al. Air pollution events from forest fires and emergency department attendances in Sydney, Australia 1996-2007: a case-crossover analysis. Environmental Health 2014;13(1):105. doi: 10.1186/1476-069X-13-105

13. Delfino RJ, Brummel S, Wu J, et al. The relationship of respiratory and cardiovascular hospital admissions to the southern California wildfires of 2003. Occup Environ Medi 2009;66(3):18997. doi: https://doi.org/10.1136/oem.2008.041376

14. Martin KL, Hanigan IC, Morgan GG, et al. Air pollution from bushfires and their association with hospital admissions in Sydney, Newcastle and Wollongong, Australia 1994-2007. Australian and New Zealand journal of public health 2013;37(3):238-43. doi: 10.1111/1753-6405.12065 [published Online First: 2013/06/05]

15. Elliott CT, Henderson SB, Wan V. Time series analysis of fine particulate matter and asthma reliever dispensations in populations affected by forest fires. Environmental Health 2013;12(1):11. doi: 10.1186/1476-069x-12-11

16. Guo Y, Gao CX, Dennekamp M, et al. The association of coal mine fire smoke with hospital emergency presentations and admissions: Time series analysis of Hazelwood Health Study. Chemosphere 2020;253:126667. doi: https://doi.org/10.1016/i.chemosphere.2020.126667 [published Online First: 2020/04/13]

17. Johnson AL, Dipnall JF, Dennekamp M, et al. Fine particulate matter exposure and medication dispensing during and after a coal mine fire: A time series analysis from the Hazelwood Health Study. Environmental Pollution 2019;246:1027-35. doi:

https://doi.org/10.1016/i.envpol.2018.12.085 
medRxiv preprint doi: https://doi.org/10.1101/2020.10.14.20213033; this version posted November 24,2020 . The copyright holder for this preprint (which was not certified by peer review) is the author/funder, who has granted medRxiv a license to display the preprint in perpetuity.

It is made available under a CC-BY-NC 4.0 International license.

18. Johnson AL, Gao CX, Dennekamp M, et al. Coal-mine fire-related fine particulate matter and medical-service utilization in Australia: a time-series analysis from the Hazelwood Health Study. International Journal of Epidemiology 2020;49(1):80-93. doi: 10.1093/ije/dyz219

19. Johnson AL, Gao CX, Dennekamp M, et al. Associations between Respiratory Health Outcomes and Coal Mine Fire PM 2.5 Smoke Exposure: A Cross-Sectional Study. International Journal of Environmental Research and Public Health 2019;16(21):4262. doi: doi:10.3390/ijerph16214262

20. Ikin J, Carroll M, Walker J, et al. Cohort Profile: The Hazelwood Health Study Adult Cohort. International Journal of Epidemiology 2020;dyaa083 doi: 10.1093/ije/dyaa083

21. Harris PA, Taylor R, Thielke R, et al. Research electronic data capture (REDCap)--a metadatadriven methodology and workflow process for providing translational research informatics support. J Biomed Inform 2009;42(2):377-81. doi: 10.1016/j.jbi.2008.08.010

22. Cooper BG. An update on contraindications for lung function testing. Thorax 2011;66(8):714-23. doi: 10.1136/thx.2010.139881 [published Online First: 2010/07/31]

23. WHO Consultation on Obesity. Obesity : preventing and managing the global epidemic : report of a WHO Consultation on Obesity, Geneva, 3-5 June 1997. Geneva: World Health Organization, 1998.

24. World Health Organization. Guidelines for controlling and monitoring the tobacco epidemic. Geneva: World Health Organization 1998.

25. Luhar AK, Emmerson KM, Reisen F, et al. Modelling smoke distribution in the vicinity of a large and prolonged fire from an open-cut coal mine. Atmos Environ 2020;229:117471. doi: https://doi.org/10.1016/j.atmosenv.2020.117471

26. European Community Respiratory Health Survey Steering Committee. The European Community Respiratory Health Survey II. Eur Respir J 2002;20(5):1071-9.

27. Miller MR, Hankinson J, Brusasco V, et al. Standardisation of spirometry. European Respiratory Journal 2005;26(2):319-38. doi: 10.1183/09031936.05.00034805

28. Quanjer PH, Stanojevic S, Cole TJ, et al. Multi-ethnic reference values for spirometry for the 395-yr age range: the global lung function 2012 equations. European Respiratory Journal 2012;40(6):1324. doi: 10.1183/09031936.00080312

29. Borg BM, Reid DW, Walters EH, et al. Bronchodilator reversibility testing: laboratory practices in Australia and New Zealand. The Medical journal of Australia 2004;180(12):610-13.

30. Graham BL, Brusasco V, Burgos F, et al. 2017 ERS/ATS standards for single-breath carbon monoxide uptake in the lung. Eur Respir J 2017;49(1) doi: 10.1183/13993003.00016-2016 [published Online First: 2017/01/04]

31. Stanojevic S, Graham BL, Cooper BG, et al. Official ERS technical standards: Global Lung Function Initiative reference values for the carbon monoxide transfer factor for Caucasians. Eur Respir J 2017;50(3) doi: 10.1183/13993003.00010-2017 [published Online First: 2017/09/13]

32. Doiron D, de Hoogh K, Probst-Hensch N, et al. Air pollution, lung function and COPD: results from the population-based UK Biobank study. Eur Respir J 2019;54(1) doi: 10.1183/13993003.02140-2018 [published Online First: 2019/07/10]

33. Huang $\mathrm{H}-\mathrm{C}$, Lin FC-F, Wu M-F, et al. Association between chronic obstructive pulmonary disease and PM2.5 in Taiwanese nonsmokers. International Journal of Hygiene and Environmental Health 2019;222(5):884-88. doi: https://doi.org/10.1016/j.ijheh.2019.03.009

34. Guo C, Zhang Z, Lau AKH, et al. Effect of long-term exposure to fine particulate matter on lung function decline and risk of chronic obstructive pulmonary disease in Taiwan: a longitudinal, cohort study. The Lancet Planetary Health 2018;2(3):e114-e25. doi: https://doi.org/10.1016/S2542-5196(18)30028-7

35. Zhao J, Li M, Wang Z, et al. Role of PM2.5 in the development and progression of COPD and its mechanisms. Respiratory Research 2019;20(1):120. doi: 10.1186/s12931-019-1081-3

36. Zeng G, Sun B, Zhong N. Non-smoking-related chronic obstructive pulmonary disease: A neglected entity? Respirology 2012;17(6):908-12. 
medRxiv preprint doi: https://doi.org/10.1101/2020.10.14.20213033; this version posted November 24,2020 . The copyright holder for this preprint (which was not certified by peer review) is the author/funder, who has granted medRxiv a license to display the preprint in

perpetuity.
It is made available under a CC-BY-NC 4.0 International license .

37. Groot $E$, Caturay A, Khan $\mathrm{Y}$, et al. A systematic review of the health impacts of occupational exposure to wildland fires. Int J Occup Med Environ Health 2019;32(2):121-40. doi: 10.13075/ijomeh.1896.01326 [published Online First: 2019/03/29]

38. Gaughan DM, Piacitelli CA, Chen BT, et al. Exposures and Cross-shift Lung Function Declines in Wildland Firefighters. J Occup Environ Hyg 2014;11(9):591-603. doi: https://doi.org/10.1080/15459624.2014.895372

39. Slaughter J, Koenig J, Reinhardt T. Association between lung function and exposure to smoke among firefighters at prescribed burns. J Occup Environ Hyg 2004;1(1):45-9. doi: https://doi.org/10.1080/15459620490264490

40. Vora C, Renvall M, Chao P, et al. 2007 San Diego Wildfires and Asthmatics. J Asthma 2011;48(1):75-8. 